\title{
Organizational Commitment and Culture of Tri Hita Karana Moderating the Effect of Budget Participation in Budgetary Slack
}

\author{
Ni Gusti Agung Windy Renggadewi \\ Herkulanus Bambang Suprasto \\ Faculty of Economics and Business, Udayana University, Bali, Indonesia
}

\begin{abstract}
This study aims to test empirically the effect of budgetary participation on budgetary slack and the ability of Tri Hita Karana's organizational commitment and culture in moderating the effect of budgetary participation on budgetary slack. The number of samples used was 44 people consisting of the Head of OPD in the Badung Regency Government, using the purposive sampling method. Data collection was carried out by means of a questionnaire. The data analysis technique used is multiple linear regression analysis containing interaction or the Moderating Regression Analysis (MRA) test. Based on the analysis, it is found that budgetary participation has a positive effect on budgetary slack. This shows that the higher the participation in budgeting, the higher the budgetary slack that will occur. Organizational commitment weakens the effect of budgetary participation on budgetary slack. High participation in budgeting reduces budgetary slack due to high organizational commitment. The Tri Hita Karana culture weakens the influence of budgetary participation on budgetary slack. High budgeting participation reduces budgetary slack due to the high implementation of Tri Hita Karana culture.
\end{abstract}

Keywords: budgetary participation, budgetary slack, organizational commitment, Tri Hita Karana culture

DOI: $10.7176 /$ RJFA/11-18-12

Publication date:September $30^{\text {th }} 2020$

\section{INTRODUCTION}

Previous studies have been conducted to determine the factors that influence the occurrence of budgetary slack. One of them which is considered influential on budgetary slack is participation in budget formulation. Participatory budgeting is a process that describes individuals involved in preparing a budget and has an effect on budget targets and the need for appreciation for achieving those budget targets. The participatory budget process is effective because there is an effective exchange of information so that the amount of the approved budget is the result of the expertise and personal knowledge of the budget maker close to the operating environment (Anthony and Govindarajan, 2007). According to Brownell (1982) Participation in budgeting is a process that involves individuals in budgeting and has an effect on budget targets and the need for rewards for the targets achieved.

Previous studies that have examined the effect of budgetary participation on budgetary slack reveal inconsistent results. According to several studies, namely Research Widyaningsih (2011), Triana (2012), Karsam (2015), Irfan et al. (2016), budgetary participation is considered to be able to trigger negative behavior that can arise from the involvement of subordinates (agents) in preparing the budget, namely by creating budgetary slack. Some of these studies show that budgetary participation has a positive effect on budgetary slack. In contrast, the study of Kahar et al. (2016), Zahra (2017) and Chong (2017) show that high participation in budgeting can also reduce budgetary slack events. In these studies budgetary participation has a negative effect on budgetary slack. From various research results that show inconsistencies between one research and another, it is assumed that there are other variables that effect the relationship between participation in budgeting and the likelihood of budgetary slack.

Anthony and Govindarajan (2007) stated that the differences in the results of these studies could be resolved through a contingency approach. This is done by including other variables that might affect the relationship between budgetary participation and budgetary slack. Organizational commitment is employee loyalty to the company or organization as measured by how strong the employee's desire is in achieving organizational goals. An employee with high organizational commitment prioritizes the interests of the organization over the interests of the individual, so the possibility of budgetary slacking is also getting smaller. Nouri and Parker (1996) state that budgetary slack can be avoided if members of organizations participating in budgeting have high organizational commitment. Conversely, if the organizational commitment is low, personal interests are prioritized so as to increase budgetary slack.

Tri Hita Karana is a Balinese cultural philosophy that emphasizes the theory of balance stating that the Hindu community in Bali tends to understand themselves and their environment as a system, which is controlled by the value of balance and manifested in the form of behavior. (Gunawan, 2008) The Government of Badung Regency uses this philosophy in the vision of the 2016-2021 Badung Regency RPJMD, namely "Strengthening the Direction of Badung Development Based on Tri Hita Karana Towards a Community that is Advanced, Peaceful and Prosperous".

Tri Hita Karana can be used as an ethical guide in an organization because in essence the understanding of 
Tri Hita Karana is the three causes of the welfare of life that is achieved through harmonious relations between humans and their God, humans with their natural environment and humans with each other. Tri Hita Karana is a "lubricant" of social machines in organizations, in other words the application of Tri Hita Karana makes social interaction with members of the organization smooth, reduces conflicts, and increases efficiency and reduces the presence of deviant behavior. The purpose of Tri Hita Karana is to create a harmonious relationship between humans and God Almighty (Parahyangan), humans with humans (Pawongan), and humans with nature or the environment (Palemahan) (Antari, 2017).

Employees who apply good Tri Hita Karana to their lives have Srada Bhakti to God Almighty, have a harmonious relationship with other individuals in the organization and keep their environment clean, comfortable, and calm. Employees with the implementation of Tri Hita Karana will avoid opportunist behavior so that budgetary slack will be avoided.

\section{LITERATURE REVIEW AND HYPOTHESIS DEVELOPMENT}

A performance-based budgeting system, which is an efficient and participatory development process in which performance is a measure of the success of an organization in carrying out government activities. However, performance appraisal based on whether or not the local budget target is reached causes budgetary slack (Kartiwa, 2004). Budgeting participation is a process of collaboration that occurs between agents and principals in making a regional budget. The intended participation in regional government is the involvement of the WTO when preparing the APBD. However, when making a budget, it is suspected that budgetary slack will occur. Participatory budgeting is one of the factors that cause budgetary slack, each individual involved in the budgeting process often looks for ease in achieving the specified budget, so that each individual performs budgetary slack by increasing costs or lowering income than they should, so that the budget is easily achieved (Anthony and Govindarajan, 2007).

This is supported by the results of Triana Research (2012), Karsam (2015), Irfan et al. (2016), budgetary participation is considered to be able to trigger negative behavior that can arise from the involvement of subordinates (agents) in preparing the budget, namely by creating budgetary slack. Some of these studies show that participatory budgeting has a positive effect on budgetary slack. In contrast, the study of Kahar et al. (2016), Zahra (2017) and Chong (2017) show that high participation in budgeting can also reduce budgetary slack events. H1: Participation in budgeting has a positive effect on budgetary slack

Organizational commitment can function as a psychological aid in running a particular organization. High organizational commitment will reduce an employee's desire to create budgetary slack. Conversely, low organizational commitment means that an employee prioritizes his personal interests and tends to make budgetary slack so that budget targets can be easily achieved and can improve performance. This is supported by Nouri and Parker (1996). Unlike the case with Andriyani and Hidayati (2010) that if the heads of each OPD participating in regional budgeting have low organizational commitment, the budgetary slack will be even lower.

Setiawan and Ghozali (2016) state that budgetary participation has a negative effect on budgetary slack when it is moderated by organizational commitment. Similarly, Irfan et al. (2016) who found low organizational commitment can strengthen the relationship of budgetary participation to budgetary slack. However, Minan (2005) states that organizational commitment does not affect the relationship between participative budgeting and budgetary slack.

H2: Organizational Commitment weakens the positive effect of budgetary participation on budgetary slack.

The concept of Tri Hita Karana culture is a harmonious relationship that is always maintained by the Balinese people, especially Hinduism. Tri Hita Karana can be interpreted as the three causes of welfare being achieved through harmony and balance of relations between humans and their Lord, humans with their natural environment and humans with each other. Yudastri (2017) states that the balance will affect business actions or activities carried out by human figures involved in the business, including in budgeting activities. Tri Hita Karana is creating harmonious relationships so that individuals tend to be kind and honest in their actions, including in the budget preparation process (Antari, 2017). Gunawan (2011) states that the belief in the harmony of harmony has become a guide for Balinese people to behave which gives birth to various concrete actions, namely: (a) The harmony of human relations with Hyang widhi (God), which is called as the devil; (b) the harmony of relationships with others is called Pawongan; (c) the harmony of human relations with the natural environment is called palemahan. If we apply Tri Hita Karana in the preparation of a budget it will be able to reduce the slack that occurs because we will tend to be honest in order to always create a harmonious relationship. Based on the description above, the second hypothesis of this study is as follows:

H3: Culture of Tri Hita Karana weakens the positive effect of budgetary participation on budgetary slack

\section{METHODS}

The location of the study in this study is the Regional Apparatus Organization (OPD) of Badung Regency. The regional apparatus organization (OPD) was chosen because OPD has the task of compiling, using, and reporting budget realization or as implementing budget from the regional government. The study period is in July - 
December 2018.

The population in this study is the Head of the Regional Apparatus Organization (OPD) of Badung Regency. Sampling in this study was conducted by non-probability sampling, namely by using a purposive sampling approach. The data analysis technique used to solve the problems in this study is Moderated Regression Analysis (MRA) using the IBM SPSS Statistics 22 program.

\section{RESULTS AND DISCUSSION}

Multiple Regression Analysis Test

The analysis used is multiple regression analysis. Regression analysis aims to determine the effect of independent variables on the dependent variable, which is measured using a regression coefficient.

Table 1. Multiple Linear Regression Test Results

\begin{tabular}{|c|c|c|c|c|c|}
\hline \multirow[t]{2}{*}{ Variable } & \multicolumn{2}{|c|}{$\begin{array}{l}\text { Unstandardized } \\
\text { Coefficients }\end{array}$} & \multirow{2}{*}{$\begin{array}{c}\begin{array}{c}\text { Standardized } \\
\text { Coefficients }\end{array} \\
\text { Beta }\end{array}$} & \multirow[t]{2}{*}{$\mathbf{t}$} & \multirow[t]{2}{*}{ Sig. } \\
\hline & $\mathrm{B}$ & Std. Error & & & \\
\hline (Constant) & 6,379 & 6,156 & & 1,036 & 0,307 \\
\hline $\mathrm{X}_{1}$ & 1,069 & 0,437 & 1,143 & 2,447 & 0,019 \\
\hline $\mathrm{X}_{2}$ & 0,410 & 0,125 & 0,753 & 3,271 & 0,002 \\
\hline $\mathrm{X}_{2}$ & $-0,32$ & 0,064 & $-0,144$ & $-0,501$ & 0,620 \\
\hline $\mathrm{X}_{1} \mathrm{X}_{2}$ & $-0,023$ & 0,009 & $-0,976$ & $-2,472$ & 0,018 \\
\hline $\mathrm{X}_{1}-\mathrm{X}_{3}$ & $-0,011$ & 0,005 & $-0,558$ & $-2,403$ & 0,021 \\
\hline Adjusted R Square & & & 0,771 & & \\
\hline F value & & & 29,955 & & \\
\hline Significance of $\mathrm{F}$ & & & 0,000 & & \\
\hline
\end{tabular}

Primary Data, 2019

F test

Table 1 explains the regression model has a p-value (Sig. F Change) of 0,000 . This value is smaller than 0.05 , so the research model is said to have fulfilled the Goodness of fit test. This means that the independent variables (budgetary participation, organizational commitment, and culture of Tri Hita Karana) can predict or explain the phenomena of budgetary slack in the Badung Regency Government, so it can be concluded that the model in this study is said to be worthy of research.

Determination Coefficient Test (R2)

The coefficient of determination test is used to measure how far the ability of a model to explain the variation of the dependent variable can be explained by the variation of the independent variables. The coefficient of determination is between 0 (zero) and 1 (one). A value close to 1 (one) means that the independent variable provides almost all the information needed to predict the dependent variables. In this study the results of the coefficient of determination test for simple linear regression analysis seen from the adjusted R2 value of 0.771 , this means that 77.1 percent of variation in budgetary slack $(\mathrm{Y})$ is influenced by budget preparation variables $(\mathrm{X} 1)$, organizational commitment (X2), and Tri Hita Karana culture (X3), the remaining 22.9 percent is influenced by other factors outside the model.

Hypothesis test ( $t$ test)

To find out how the organizational commitment variable (X2) and the culture of Tri Hita Karana (X3) moderate the influence of budgeting participation (X1) on budgetary slack (Y), a Moderated Regression Analysis (MRA) test is performed. The results of the multiple linear regression analysis can be seen in Table 5.9, with the following regression equation:

$$
\mathrm{Y}=6,379+1,069 \mathrm{X} 1+0.410 \mathrm{X} 2-0.32 \mathrm{X} 3-0.023 \mathrm{X} 1 \mathrm{X} 2-0.011 \mathrm{X} 1 \mathrm{X} 3+\mathrm{e} \ldots \text { (1) }
$$

Based on equation (1) above, it can be explained the constant value (a) of 6.379 shows a positive value, meaning that when the budgeting participation variable (X1), organizational commitment (X2), Tri Hita Karana culture (X3), interactions between budgeting participation with organizational commitment (X1_X2), and interaction between budgeting participation with the culture of Tri Hita Karana (X1_X3) each of which is zero (0), then budgetary slack (Y) will still occur.

The budgetary participation variable has a coefficient value of $\beta 1$ of 1.069 and a significance level of $t$ of 0.019 which is smaller than $\alpha=0.05$ so that $\mathrm{H} 1$ is accepted. The value of the regression coefficient explains every increase in the budget participation variable then the value of the budgetary slack will increase with the assumption that the other independent variables are constant.

The organizational commitment variable has a coefficient value of $\beta 2$ of 0.410 and a significance level of $t$ of 0.002 which is smaller than $\alpha=0.05$. The value of the regression coefficient explains each increase in organizational commitment variables, the value of budgetary slack will increase with the assumption that the other independent variables are constant.

The cultural variable Tri Hita Karana has a coefficient value of $\beta 3$ of -0.32 and a significance level of $t$ of 
0.620 which is smaller than $\alpha=0.05$. The value of the regression coefficient explains each increase in the cultural variable Tri Hita Karana, the value of the budgetary slack will decrease with the assumption that the other independent variables are constant.

The budgetary participation variable with organizational commitment has a coefficient value of $\beta 4$ of -0.023 and a significance level of $t$ of 0.018 which is smaller than $\alpha=0.05$ so that $\mathrm{H} 2$ is accepted. The value of the regression coefficient explains that every increase in the interaction variable of budgeting participation and organizational commitment then the value of the budgetary slack will decrease with the assumption that the other independent variables are constant.

The budgetary participation variable with the culture of Tri Hita Karana has a coefficient value of $\beta 5$ of 0.011 and a significance level of $t$ of 0.021 which is smaller than $\alpha=0.05$ so that H3 is accepted. The value of the regression coefficient explains that every increase in the interaction variables of budgeting participation and religious ethics, the value of budgetary slack will decrease with the assumption that the other independent variables are constant.

Effects of Budgetary Participation in Budgetary Slack

A performance-based budgeting system uses performance as a benchmark for the success of a government administration organization. The performance in question is the achievement of revenue budget targets and budget efficiency in the APBD. The APBD preparation system uses a participatory budget system that involves managers and leaders at lower levels to get involved in budgeting.

Agency Theory explains the relationship between subordinates (agents) and superiors (principals) that occur due to information asymmetry and conflicts of interest between agents and principals. In the process of preparing the OPD budget as an agent and the Regional Leader as the principal. OPD participation in budgeting is used as an opportunity to make good performance evaluations. Individual motivation creates slack on the budget prepared to show maximum performance in front of his superiors. Budget makers have the opportunity for their personal interests by making budget achievements that are easily achieved, such as determining income targets that are too low (understated) and costs that are too high (overstated). Low income targets are created with the aim that the budget makers are not difficult to achieve high income and vice versa. The higher the level of participation or involvement of a person in the preparation of the budget, the dysfunctional behavior such as creating a slack on the budget prepared tends to increase.

Budgeting participation provides the authority and opportunity for budget makers to determine the contents of their budget, while on the one hand their performance will be assessed based on the budget, thus opening opportunities for these officials to behave dysfunctionally by manipulating information and performance measures. This is done by deliberately creating the best information in accordance with the circumstances and that will benefit them, so that their goals are achieved.

The results of the first hypothesis test (H1) show that budgetary participation has a positive effect on budgetary slack in the Government of Badung Regency OPD, which means that the higher the budgeting participation, the higher the budgetary slack in the Government of Badung Regency OPD. The results of this study are consistent with the results of research conducted by Triana (2012), Karsam (2015), Irfan et al. (2016), Perdana (2016), Astuti (2017), Ermawati (2017) and Muliansyah (2017) which show the results that budgeting participation has a positive effect on budgetary slack. These results also support the study of Widanaputra and Mimba (2014) which explains that there is a relationship between agents and principals where agents are motivated to make budgetary slack to maximize their interests in budgeting.

Interaction of Organizational Commitment with the Influence of Participation in Budgeting on Budgetary Slack Wiener (1982) defines organizational commitment as an encouragement from within individuals to do something in order to support the success of the organization in accordance with the objectives and prioritizes the interests of the organization rather than its own interests. Organizational commitment can function as a psychological aid in running a particular organization. High organizational commitment will reduce an employee's desire to create budgetary slack. Conversely, low organizational commitment means that an employee prioritizes his personal interests and tends to make budgetary slack so that budget targets can be easily achieved and can improve performance.

Setiawan and Ghozali (2016) state that budgetary participation has a negative effect on budgetary slack when it is moderated by organizational commitment. Similarly, Irfan et al. (2016) who found low organizational commitment can strengthen the relationship of budgetary participation to budgetary slack.

The results of the second hypothesis test (H2) state that organizational commitment weakens the relationship between budgeting participation in budgetary slack. Participation in high budgeting reduces budgetary slack due to high organizational commitment. The higher organizational commitment, the lower the tendency for the head of the OPD to create budgetary slack. The results of this study support the research of Latuheru (2006) and Apriantini (2014) which shows that an increase in organizational commitment will cause a decrease in budgetary slack for individuals participating in budgeting. Conversely, a decrease in organizational commitment can result in a tendency to create budgetary slack. 
The Cultural Interaction of Tri Hita Karana with the Effects of Budgetary Participation on Budgetary Slack

Tri Hita Karana's philosophy is determined by the teachings of Hinduism which were extracted from the teachings of Bhagawadgita. Tri Hita Karana's religious ethics is a balance that emphasizes the relationship that humans are determined by three relationships, namely the relationship between humans and God (Parahyangan), humans with humans (Pawongan), and humans with the environment (Palemahan). Balance in maintaining relationships with God, humans, and the environment will certainly affect every action taken by humans, including in budgeting activities. Awareness of the existence of three relationships in the teaching of religious ethics, causing these officials to take actions in accordance with their functions.

Parahyangan can be realized through sradha and bhakti namely belief in God, so that in carrying out its duties the budget compilers are not only accountable for any actions taken to superiors but also to God Almighty. In addition, there is a belief in the law of the Kharma Phala, which is that there is always the result of every action done so that someone will try to do good things in order to receive good results as well.

Pawongan explains the relationship of humans with each other through the concept of menyamabraya, Tat Twam Asi, and salunglung sabayantaka. These three concepts if applied by individuals when preparing a budget are able to create harmonious relationships such as not prioritizing their personal interests by creating slacks or making budget targets that are easily achieved with the aim of being able to improve performance in front of superiors.

Furthermore, Palemahan explains the relationship between humans and nature or the environment. Implementation of a harmonious relationship with the environment when preparing a budget can be done by budgeting regional revenues for activities related to social activities or religious activities related to the environment so that funds that have been budgeted for these activities can actually be realized.

The results of the third hypothesis test (H3) state that the Tri Hita Karana culture weakens the effect of budgetary participation on budgetary slack. High participation in budgeting reduces budgetary slack due to the high implementation of the Tri Hita Karana culture. The higher the implementation of the Tri Hita Karana culture, the lower the tendency for OPD heads to create budgetary slack. The results of this study are in line with research conducted by Sukayana and Asri (2019), Yudastri (2017) and Antari (2017) which also stated that Tri Hita Karana weakens the effect of budgetary participation on budgetary slack.

\section{CONCLUSION}

Participation in budgeting was able to increase budgetary slack in OPD Badung Regency. This means that the higher a person's participation in the preparation of a budget, the higher the slack that occurs in the budget. High participation in budgeting reduces budgetary slack due to high organizational commitment to employees in the Badung Regency Government, for this reason the Badung Regency Government must maintain it by continuing to hold character building activities for every individual involved in budgeting through formal or informal education processes. High participation in budgeting reduces budgetary slack due to the application of the high Tri Hita Karana culture by Badung Regency Government employees, for this reason the Badung Regency Government should maintain its activities in implementing the Tri Hita Karana culture.

\section{References}

Antari, Ni Koman Anik Wahyuni dan I Made Sukartha. 2017. Pengaruh Partisipasi Penyusunan Anggaran dan Informasi asimetri pada Senjangan Anggaran dengan Budaya Organisasi sebagai Pemoderasi. E-Jurnal Akuntansi Universitas Udayana. Vol: 20(2), hal: 929-958.

Anthony, R.N., dan V. Govindarajan. 2007. Management Control Syste., McGraw Hill, New York.

Apriantini, Ni Kadek Erni. 2014. Pengaruh Partisipasi Anggaran terhadap Senjangan Anggaran dengan Penekanan Anggaran dan Komitmen Organisasi sebagai Variabel Moderating (Studi Kasus pada Dinas-Dinas Pemerintahan Kabupaten Buleleng. Jurnal Akuntansi Universitas Pendidikan Ganesha, Vol. 2, No:1

Astuti, Sang Ayu Putu Puji, Dewa Gede Wirama dan Ni Ketut Rasmini. 2017. Pengendalian Anggaran Yang Ketat dan Orientasi Waktu sebagai Pemoderasi Pengaruh Anggaran Partisipatif pada Senjangan Anggaran. EJurnal Ekonomi dan Bisnis Universitas Udayana 6(2), hal: 619-646

Brownell, P. 1982. The Role of Accounting Data in Performance Evaluation, Budgetary Participation, and Organizational Effectiveness. Journal of Accounting Research, Vol. 20, pp: 12-27.

Chong,Vincent K, dan Raymon Strauss. 2017. Participative Budgeting : The Effects of Budget Emphasis, Information Asymmetry and Procedural Justice on Slack - Additional Evidence. Asia-Pacific Management Accounting Journal. Volume 12 Issue 1.

Ermawati, Nanik. 2017. Pengaruh Partisipasi Anggaran terhadap Kinerja Manajerial dengan Motivasi Kerja sebagai Pemoderasi. Jurnal Akuntansi Indonesia, 6(12), hal: 141-156.

Etemadi, Hossein and Saeed Sirghani. 2016. The Effects of Budget Slack Creation and Budget Internal Control by Managers on Maximization of Utility Function in Budgetary Participation. International Journal of Finance and Managerial Accounting. Vol. 1. No. 2. 
Govindarajan, V. 1986. Impact Of Participation In The Budgetary Process On Managerial Attitudes And Performance: Universalistic And Contingency Perspectives. Decision Sciences, 17(4), pp : 496-516

Gunawan, Ketut. 2011. Peran Falsafah Tri Hita Karana Bagi Pertumbuhan dan Kinerja Lembaga Perkreditan Desa (LPD) di Bali. Analisis Manajemen. Vol. 5. No. 2.

Hofstede, G. 2011. Dimensionalizing Cultures : The Hofstede Model in Context. Online Readings in Psychology and Culture. Vol. 2.

Irfan, Muh, Budi Santoso dan Lukman Effendi. Pengaruh Partisipasi Anggaran terhadap Senjangan Anggaran dengan Asimetri Informasi, Penekanan Anggaran dan Komitmen Organisasional sebagai Variabel Pemoderasi. Jurnal Akuntansi dan Investasi. 17(2), hal: 158-175.

Karsam. 2013. The Influence of Participation in Budgeting on Budgetary Slack with Information Asymetry as a Moderating Variable and Its Impact on the Managerial Performance (A Study on Yayasan Pendidikan dan Koperasi in the Province of Banten, Indonesia). International Journal of Applied Finance and Business Studies, 1(I), pp: 28-38.

Latuheru, Belianus P. 2006. Pengaruh Partisipasi Anggaran Terhadap Senjangan Anggaran Dengan Komitmen Organisasi Sebagai Variabel Moderating. Jurnal Akuntansi dan SistemTeknologi Informasi. Vol:5(1), Hal:24-38.

Lowe, E. A. dan R. W. Shaw. 1968. An Analysis of Managerial Biasing: Evidence From a Company's Budgeting Proses. The Journal of Management Studies 5. pp: 304-315.

Muliansyah, Budi. 2017. "Analisis Pengaruh Penganggaran Partisipatif terhadap Budgetary Slack pada Pemerintah Kabupaten Dompu”. (tesis). Universitas Mataram.

Nouri, H., dan R.J. Parker. 1996. The Effect of Organizational Comitment on Relation Between Budgetary Participation and Budgetary Slack. Behavioral Research in Accounting, pp: 74-89.

Perdana, Kadek Wisnu dan Gerianta Wirawan Yasa. 2016. Pengaruh Partisipasi Penyusunan Anggaran pada Budgetary Slack dengan Komitmen Organisasi dan Etika sebagai Variabel Moderasi. E-Jurnal Akuntansi Universitas Udayana 18(3), hal: 2346-2372.

Setiawan, Bambang M. dan Imam Gozali. 2016. The Effect of Budget Participation on Budgetary Slack in Local Government with Organizational Commitment and Environmental Uncertainty as The Moderating Variable. Ijaber. Vol.14, No. 10.

Sukayana, Gede Adi, IGAM Asri Dwija Putri. 2017. Tri Hita Karana Culture an Organizational Commitments Moderate : Effect of Participation on Budgetary Slack. International Research Journal of Management, IT and Social Sciences. pp: 180-188.

Susana Gago-Rodríguez, David Naranjo-Gil. 2016. Effects of Trust and Distrust on Effort and Budgetary Slack: an Experiment. Management Decision, 54(8), pp: 1908-1928.

Widanaputra, A.A. and Mimba, N.P.S.H. 2014. The Influence of Participative Budgeting on Budgetary Slack in Composing Local Governments Budget in Bali Province.Procedia - Social and Behavioral Sciences. Volume 164, pp: 391-396.

Wiener, Y. 1982. Commitment in Organization: A Normative View. Academy of Management Review 7. pp. 418428

Yudastri, Ni Ketut, I Ketut Budiartha dan I Dewa Nyoman Badera. 2017. "Budaya Tri Hita Karana sebagai Pemoderasi Pengaruh Penganggaran Partisipatif, Pengendalian Anggaran dan Standar Operasional Prosedur pada Perilaku Disfungsional”. (tesis). Denpasar: Universitas Udayana.

Zahra, Femilia. 2017. The Impact of Participative Budgeting on Budgetary Slack : A Meta-Analysis. International Journal of Mechanical Engineering and Technology (IJMET). Vol. 8. Pp.822-830. 